\title{
KAJIAN MACAM POLA TANAM JAJAR LEGOWO DAN KOMBINASI PUPUK TERHADAP PERTUMBUHAN DAN PRODUKSI TANAMAN PADI (Oryza sativa L.)
}

\author{
Muhammad Usman, Choirul Anam, Mariyatul Qibtiyah \\ Fakultas Pertanian Universitas Islam Darul 'Ulum Lamongan Jawa Timur
}

Korespondensi : usman.muhammad.t22@gmail.com

\begin{abstract}
ABSTRAK
Penelitian dilakuakan di Desa Botoputih Kecamatan Tikung, Kabupaten Lamongan. Ketinggian tempat $\pm 6 \mathrm{Mdpl}$. Penelitian pada bulan Februari - April 2019. Penelitian ini menggunakan metode Rancangan Acak Kelompok (RAK) Faktorial, terdiri dari dua faktor, setiap faktor terdiri dari 3 level yang diulang 3 kali ulangan yaitu: Faktor pola tanam jajar legowo (J) terdiri dari 3 perlakuan yaitu : Pola tanam jajar legowo 2:1 (J1), Pola tanam jajar legowo 3:1 (J2), Pola tanam jajar legowo 4:1 (J3). Faktor kombinasi pupuk (P) terdiri dari 3 perlakuan yaitu Kombinasi pupuk Petroganik $500 \mathrm{~kg} \mathrm{ha}^{-1}+$ PHONSKA $300 \mathrm{~kg}$. ha ${ }^{-1}+$ Urea $200 \mathrm{~kg}$. $\mathrm{ha}^{-1}(\mathrm{P} 1)$, Kombinasi pupuk Petroganik $500 \mathrm{~kg} \mathrm{ha}^{-1}+$ Urea $300 \mathrm{~kg}$. ha ${ }^{-1}+\mathrm{SP} 3675 \mathrm{~kg}$. ha ${ }^{-1}+\mathrm{KCl} 50$ kg. ha ${ }^{-1}(P 2)$, Kombinasi pupuk Petroganik $500 \mathrm{~kg} \mathrm{ha}^{-1}+\mathrm{ZA} 300 \mathrm{~kg} \cdot \mathrm{ha}^{-1}+\mathrm{SP} 3675 \mathrm{~kg} \cdot \mathrm{ha}^{-1}+\mathrm{KCl}$ $50 \mathrm{~kg}$. ha ${ }^{-1}(\mathrm{P} 3)$. Parameter yang diamati meliputi : tinggi tanaman, jumlah anakan, jumlah anakan produktif, panjang malai, jumlah gabah per malai, berat gabah basah per sampel, berat gabah kering per sampel, berat gabah kering per hektar dan berat 1000 biji. Data dari hasil pengamatan dihitung dengan analisa sidik ragam yang dilanjutkan dengan Uji BNT 5\%. Penelitian ini bertujuan mengetahui pengaruh perlakuan pola tanam jajar legowo dan kombinasi pupuk yang terbaik terhadap pertumbuhan dan produksi padi. Hasil pelakuan dengan prodoktifitas tertinggi yaitu J1P3 (Pola tanam Jajar Legowo 2:1 dan Kombinasi pupuk Petroganik $500 \mathrm{~kg} \mathrm{ha}^{-1}+$ ZA $300 \mathrm{~kg}$. ha ${ }^{-1}+$ SP-36 $75 \mathrm{~kg}$. ha $\left.{ }^{-1}+\mathrm{KCl} 50 \mathrm{~kg} . \mathrm{ha}^{-1}\right)$.
\end{abstract}

Kata kunci : Padi, Jajar legowo, Kombinasi pupuk,

\begin{abstract}
This research was conducted in Botoputih Village, Tikung District, Lamongan Regency. Altitude of \pm 6 Masl. Research in February - April 2019. Using Factorial Randomized Block Design (RBD) method, which consists of two factors each factor consists of 3 levels which are repeated 3 times, i.e. : Jajar Legowo cropping factor $(\mathrm{J})$ consists of 3 treatments, namely : Jajar Legowo 2:1 cropping pattern (J1), Jajar Legowo 3:1 cropping pattern (J2), Jajar Legowo 4:1 cropping pattern (J4). The fertilizer combination factor (P) consists of 3 treatments, namely : fertilizer combination of Petroganik $500 \mathrm{~kg}$. ha-1 + PHONSKA $300 \mathrm{~kg}$. ha-1 + Urea $200 \mathrm{~kg}$. ha-1 (P1), fertilizer combination of Petroganik $500 \mathrm{~kg}$. ha-1 + Urea $300 \mathrm{~kg}$. ha-1 + SP-36 75 kg. ha-1 + $\mathrm{KCl} 50 \mathrm{~kg}$. ha-1 (P2), fertilizer combination of Petroganik $500 \mathrm{~kg}$. ha-1 + ZA $300 \mathrm{~kg}$. ha-1 + SP-36 $75 \mathrm{~kg}$. ha-1 $+\mathrm{KCl} 50 \mathrm{~kg}$. ha-1 (P3). The parameters observed included: tall plants, number of tillers, number of productive tillers, panicle length, number of grain per panicle, weight of wet grain per sample, weight of dry grain per sample, weight of dry grain per hectare and weight of 1000 seeds. Data from observations are calculated by analysis of variance followed by a $5 \%$ Least Significance Different (LSD) Test. This study aims to determine the effect of the treatment of legowo jajar cropping patterns and the best combination of fertilizers on rice growth and production. Treatments that provide high productivity are J1P3 (Jajar Legowo 2:1 cropping pattern and fertilizer combination of of Petroganik $500 \mathrm{~kg}$ ha-1 + ZA $300 \mathrm{~kg}$. ha-1 + SP-36 75 kg. ha-1 + KCl 50 kg. ha-1)
\end{abstract}

Kata kunci : Oryza sativa L. , Jajar Legowo cropping, fertilizer combination 


\section{PENDAHULUAN}

Padi (Oryza sativa L.) adalah tanaman yang bernilai ekonomi tinggitdan sebagai kebutuhan pangan pokok masyarakat. Kebutuhan pangan meningkat seiring pertumbuhan jumlah penduduk, sehingga diharapkan produktifitas padi naik. Menurut data kementrian pertanian pada tahun 2017 jumlah penduduk indonesia adalah 261,89 juta jiwa sedangkan angka produksi padi mencapai 81,3 juta ton jika dikonversikan beras sejumlah 47,29 juta ton. Angka kebutuhan beras nasional mencapai 33,47 juta ton, dengan asumsi konsumsi per kapita ratarata 114,6 kg per tahun (Anonimous,2017).

Akhir ini selain faktor luas lahan yang semakin berkurang, faktor yang berdampak terhadap produktivitas padi di Indonesia diantaranya adalah produktifitas lahan dan perlunya penerapan teknologi baru dalam budidaya. Perlunya penggunaan teknologi budidaya dalam usaha tani padi sawah oleh petani dengan tujuan dapat meningkatkan produktifitas, efisiensi usaha, nilai tambah produk yang dihasilkan serta meningkatkan perekonomian petani.

Teknologi budidaya padi sawah yang dikembangkan saat ini salah satunya adalah pola tanam jajar legowo. Sistem pola tanam jajar legowo adalah rekayasa teknologi guna mendapatkan ruang terbuka yang lebih lebar antara dua kelompok barisan tanaman sehingga dapat memperbanyak cahaya matahari masuk ke setiap rumpun padi guna mengoptimalkan proses fotosintesis yang berpengaruh pada peningkatan produktivitas tanaman (Abdulrachman et al. 2013). Namun jajar legowo memiliki karakteristik masingmasing pada berbagai pola tanamnya.
Selain penggunaan teknologi dalam budidaya tanaman padi di sawah, pemupukan juga dapat menunjang produktifitas tanaman. Namun akir ini sering dijumpai lahan dengan produktivitas rendah, disebabkan karena beberapa hal, salah satunya akibat penggunaan varietas padi yang membutuhkan suplai pupuk sintetik relatif tinggi. Hal demikian dimungkinkan penggunaan pupuk akan berlebihan. Pemupukan yang tidak berimbang berdampak pada rusaknya struktur tanah dan berkurangnya input bahan organik. Sehingga dapat mempengaruhi menurunya produktifitas tanaman. Pemupukan yang berimbang akan mempengaruhi pertumbuhan dan hasil yang baik (Rahmadan ,2014)

Sebagian besar para petani di wilayah Kabupaten Lamongan masih menggunakan sistem tanam padi konvensional menggunakan tegel dengan jarak tanam $20 \times 20$ atau lebih rapat dan penggunaan pupuk tidak berimbang. Berdasarkan hasil survei yang dilaporkan Balai Pusat Statistik Kabupaten Lamongan pada tahun 2017 produksi padi di Kabupaten Lamongan 1.087.985 ton dengan luasan panen 157.679 hektar, Sumbangsi Kecamatan Tikung dengan luasan lahan panen 7.646 hektar dengan produktivitas $7 \mathrm{t}$.ha ${ }^{-1}$ dapat memproduksi 53.428 ton. Dengan penggunaan teknologi budidaya jajar legowo dan penggunaan pupuk yang berimbang diharapkan akan meningkatkan produksi padi khususnya di wilayah Lamongan.

Berdasarkan latar belakang tersebut, maka penulis akan melakukan penelitian dengan judul "Kajian macam pola tanam jajar legowo dan kombinasi pupuk terhadap pertumbuhan dan produksi tanaman padi (Oriza sativa L.). Penelitian 
ini bertujuan untuk mengetahui pengaruh dari perlakuan pola tanam jajar legowo dan kombinasi pupuk yang terbaik terhadap pertumbuhan dan produksi padi (Oryza sativa $\mathrm{L}$ ).

\section{BAHAN DAN METODE}

\section{Tempat Dan Waktu Penelitian}

Penelitian dilaksanakan di Desa Botoputih, Kecamatan Tikung, Kabupaten Lamongan. Ketinggian tempat $\pm 6 \mathrm{Mdpl}$. Waktu penelitian dilaksanakan pada bulan Februari - April 2019.

\section{Bahan Dan Alat}

Bahan yang digunakan adalah varietas benih padi Sertani 14 (MSP 14), serta menggunakan pupuk (Petroganik, Urea, Phonska, SP-36, KCl Dan ZA). Alat yang di gunakan adalah : cangkul, sabit, pompa air, mesin perontok, alat pengukur jarak tanaman, timbangan, papan nama, ATK, dll.

\section{Metode Penelitian}

Penelitian ini dilakukan dengan menggunakan metode Rancangan Acak Kelompok (RAK) faktorial, yang terdiri dari dua faktor dan setiap faktor terdiri dari 3 level yang di ulang 3 kali ulangan, yaitu:

Faktor I: Macam Pola tanam Jajar Legowo

(J) terdiri 3 level yaitu:

J1 : Pola tanam Jajar Legowo $2: 1$

J2 : Pola tanam Jajar Legowo $3: 1$

J3 : Pola tanam Jajar Legowo 4 : 1

Faktor II: Macam kombinasi pupuk (P) terdiri dari 3 level yaitu:

P1 : Kombinasi pupuk Petroganik $500 \mathrm{~kg} \mathrm{ha}{ }^{-}$ ${ }^{1}+$ PHONSKA 300 kg. ha ${ }^{-1}+$ Urea 200 kg. ha ${ }^{-1}$

P2 : Kmbinasi pupuk Petroganik $500 \mathrm{~kg} \mathrm{ha}^{-1}$ + Urea $300 \mathrm{~kg} \cdot \mathrm{ha}^{-1}+\mathrm{SP}-3675 \mathrm{~kg} \cdot \mathrm{ha}^{-1}$ $+\mathrm{KCl} 50 \mathrm{~kg} \cdot \mathrm{ha}^{-1}$
P3 : Kombinasi pupuk Petroganik $500 \mathrm{~kg}$ $\mathrm{ha}^{-1}+$ ZA $300 \mathrm{~kg} \cdot \mathrm{ha}^{-1}+$ SP-36 $75 \mathrm{~kg} \cdot \mathrm{ha}^{-1}$ $+\mathrm{KCl} 50 \mathrm{~kg} \cdot \mathrm{ha}^{-1}$ )

Dari kedua faktor tersebut diperoleh 9 kombinasi perlakuan. Kombinasi tersebut diulang tiga kali ulangan sehingga diperoleh $9 \times 3=27$ kombinasi ulangan perlakuan (27 petak percobaan).

\section{Pelaksanaan Penelitian}

\section{Pengolahan Lahan}

Sebelum tanah diolah, tanah digenangi air terlebih dahulu hingga rata dengan ketinggian air $5 \mathrm{~cm}$ diatas permukaan tanah untuk memudahkan pengolahan. Kemudian dilakukan pembajakan dan perataan tanah. Kedalaman lapisan olah tanah berkisar 30 $\mathrm{cm}$. Diratakan sebaik mungkin sehingga saat diberikan air ketinggiannya di petakan sawah akan merata.Pengolahan tanah ini bertujuan untuk memberikan pertumbuhan padi yang optimal dan gulma yang ada dapat dibenamkan dengan sempurna.

Setelah dilakukan pengolahan, tanah olahan dipetak - petak sesuai dengan perlakuan, ukuran masing-masing petak 2 X 2 meter. Diantara petak dan ulangan dibuatkan saluran air sekaligus sebagai pembatas antar petak dan ulangan.

\section{Persemaian}

Benih yang digunakan adalah varietas Sertani 14. kebutuhan benih padi berkisar $7 \mathrm{~kg}$. ha ${ }^{-1}$.Sebelum perendaman benih dilakukan uji benih dengan air garam. Kemudian benih direndam dalam air selama 24 jam, ditiriskan dan diperam 2 hari ditempat yang lembab hingga keluar calon tunas dan kemudian disemaikan pada lahan persemaian yang sudah disiapkan. 


\section{Penanaman}

Bibit digunakan pada saat benih berusia 12 hari setelah semai (HSS). Bibit dipersemaian dicabut dan ditanam menggunakan sistem tanam jajar legowo. Sesuai dengan masing-masing perlakuan pada petakan penelitian, dengan 3 macam pola tanam berbeda.

Pola tanam jajar legowo 2 : 1 yakni dengan jarak tanam $20 \mathrm{~cm} \times 15 \mathrm{~cm}$ x $40 \mathrm{~cm}$ dan sisipan diberikan disemua barisan, yang perpetaknya terdiri dari 104 tanaman.

Pola tanam jajar legowo 3 : 1 yakni dengan jarak tanam $20 \mathrm{~cm} \times 15 \mathrm{~cm}$ × $40 \mathrm{~cm}$ dan sisipan diberikan disemua barisan, yang perpetaknya terdiri dari 117 tanaman.

Pola tanam jajar legowo 4 : 1 yakni dengan jarak tanam $20 \mathrm{~cm}$ x $15 \mathrm{~cm}$ x $40 \mathrm{~cm}$, dan sisipan diberikan disemua barisan, yang perpetaknya terdiri dari 104 tanaman.

Benih ditanam dangkal antara 0,5 $\mathrm{cm}$ hingga bagian bulir terbenam, benih tetap dipertahankan dan kondisi akar pada posisi horizontal sehingga membentuk huruf L. Hal ini dilakukan untuk menjaga aktivitas proses membangun energi dan penumbuhan nutrisi didalam tanaman agar tidak terhenti, diharapkan akar tanaman langsung tumbuh dan nutrisi pada bulir tetap efektif yang digunakan untuk pertumbuhan tanaman tersebut.

\section{Pemeliharaan Tanaman}

\section{Penyulaman}

Penyulaman dilakukan dengan mengganti tanaman yang tidak bisa tumbuh secara baik atau mati yang dilakukan ketika umur tanaman 7 hari setelah tanam, dengan tujuan agar pertumbuhan tanaman lebih seragam. Tanaman sulaman tidak digunakan sebagai sampel.

\section{Pemupukan}

Pemupukan dilakukan dengan cara ditebar pada baris tanaman secara merata, pada saat air macak-macak. Pemupukan dasar diberikan 7 hari sebelum tanam sebagai pupuk dasar. Pemupukan dilakukan dua kali mulai umur 7 HST. dengan interval 14 hari sesuai dengan kebutuhan per petak sebagai berikut :

Kombinasi pupuk (P1) : Pemupukan dasar Petroganik 200 g, Pemupukan I : Urea 80 g dan Phonska 40 g, Pemupukan II : Phonska $80 \mathrm{~g}$

Kombinasi pupuk (P2) : Pemupukan dasar Petroganik 200 g, Pemupukan I : Urea 120 g, Pemupukan II : SP-36 $30 \mathrm{~g}+\mathrm{KCl} 20 \mathrm{~g}$ Kombinasi pupuk (P3) : Pemupukan dasar Petroganik 200 g, Pemupukan I : ZA 120 g, Pemupukan II : SP-36 $30 \mathrm{~g}+\mathrm{KCl} 20 \mathrm{~g}$

\section{Pengairan}

Metode pemberian air pada padi sawah adalah pada saat tanam sampai 3 hari setelah tanam dengan kondisi air cukup. 4 HST sampai 10 HST dengan kondisi air setinggi $5 \mathrm{~cm} .11$ HST sampai memanjang berbunga air dibiarkan mengering sendiri selama 5 hari, setelah kering pemberian air setinggi $5 \mathrm{~cm}$ dan kemudian dibiarkan lagi mengering sendiri, dan pada fase berbunga sampai 10 hari sebelum panen sampai petakan di keringkan.

\section{Penyiangan}

Penyiangan dilakukan secara manual dengan cara mencabut gulma secara langsung dengan tangan atau menggunakan alat tradisional. Penyiangan dilakukan jika keberadaan gulma dapat memberikan persaingan perebutan unsur hara antara tanaman yang budidayakan dengan gulma tersebut. 


\section{$\begin{array}{lll}\text { Pengendalian } & \text { OPT } & \text { (Organisme }\end{array}$ Pengganggu Tanaman) \\ Pengendalian hama dan penyakit ini dilakukan apabila pada tanaman terjadi gejala serangan hama penyakit, dan mengunakan cara pengendalian hama penyakit terpadu (PHT). Penerapan PHT ini harus dilakukan secara kesinambungan. Penyemprotan pestisida dilakukan 10 hari sekali mulai 14 HST.}

\section{Pemanenan}

Pemanenan dilakukan apabila kadar air gabah sekitar $23-25 \%$ dan $95 \%$ semua butir padi telah menguning. Kegiatan pemanenan dilakukan dengan memotong mengunakan sabit yang kemudian dilanjutkan dengan perontokan dengan mesin perontok. Pemanenan antara petak perlakuan satu dengan lainnya dipisahkan, yang bertujuan agar diketahui hasil produksi dari tiap petak perlakuan

\section{Pengeringan}

Pengeringan yang dilakukan adalah dengan cara alami, yaitu penjemuran dengan sinar matahari yang di hamparkan di atas lantai semen atau terpal. Tujuan pengeringan adalah untuk mengurangi kadar air dalam gabah agar aman untuk disimpan atau memudahkan penanganan selanjutnya.

\section{Pengamatan}

Pengamatan dilakukan untuk mengetahui pengaruh dari masing-masing perlakuan. Pengamatan pertumbuhan dengan mengamati lima taman contoh (sampel) untuk setiap petak perlakuan. Pengamatan vegetatif dimulai setelah pindah tanam dengan interval 14 hari sekali mulai umur 14 HST. Sedangkan pengamatan fase generatif juga dilakukan tiap 14 hari sekali mulai umur 42 HST sampai panen. Denah petak percobaan dan pengambilan sampel pada petak perlakuan disajikan pada lampiran.

\section{Parameter Pertumbuhan}

-Fase Vegetatif, meliputi:

\section{Tinggi tanaman}

Tinggi tanaman diukur mulai pangkal sampai titik tetinggi tanaman pada 14 HST hingga 56 HST setiap tanaman sampel.

\section{Jumlah anakan}

Jumlah anakan yang terbentuk dihitung pada tanaman mulai umur 14 HST hingga 56 HST pada setiap tanaman sampel.

-Fase Generatif, meliputi:

\section{Jumlah Anakan Produktif}

Menghutung jumlah anakan produktif yang terbentuk pada tanaman berumur 56 HST pada setiap tanaman sampel.

\section{Panjang malai}

Mengukur mulai dari buku terakhir hingga ujung malai, dengan cara mengambil malai secara acak pada tanaman sampel pada umur 56 HST dan 70 HST.

\section{Jumlah Gabah per Malai}

Menghitung jumlah gabah per malai tiap perlakuan dengan mengambil salah satu malai secara acak pada tanaman sampel pada umur 70 HST

\section{Berat Gabah Basah per sampel}

Menimbang berat gabah basah tiap perlakuan diambil dari per tanaman Sampel (gabah usai dipanen). 


\section{Berat Gabah Kering per sampel}

Menimbang berat gabah kering tiap perlakuan diambil dari per tanaman Sampel (gabah usai dipanen).

\section{Berat Gabah Kering per hektar}

Melakukan ubinan selanjutnya penghitungan menggunakan rumus :

$\frac{\text { Luas } 1 \text { hektar }}{\text { Luas ubinan }} X$ Produksi ubinan.

\section{Berat 1000 biji}

Menimbang berat gabah kering 1000 biji pada tiap perlakuan.

\section{Pengolahan Data}

Data yang diperoleh dari hasil pengamatan dihitung dengan analalisa

Tabel 1. Rata rata tinggi tanaman

\begin{tabular}{ccccc}
\hline \multirow{2}{*}{ Perlakuan } & \multicolumn{5}{c}{ Rata-rata tinggi tanaman $(\mathrm{cm})$ pada umur } \\
\cline { 2 - 5 } & $14 \mathrm{HST}$ & $28 \mathrm{HST}$ & $42 \mathrm{HST}$ & $56 \mathrm{HST}$ \\
\hline J1P1 & $30.73 \mathrm{~d}$ & $66.00 \mathrm{~d}$ & $104.00 \mathrm{~d}$ & $119.93 \mathrm{~d}$ \\
J1P2 & $30.87 \mathrm{~d}$ & $67.20 \mathrm{~cd}$ & $104.40 \mathrm{~cd}$ & $120.00 \mathrm{~d}$ \\
J1P3 & $31.07 \mathrm{~cd}$ & $67.33 \mathrm{~cd}$ & $104.87 \mathrm{~cd}$ & $120.93 \mathrm{~cd}$ \\
J2P1 & $31.33 \mathrm{~cd}$ & $67.80 \mathrm{bc}$ & $105.67 \mathrm{bcd}$ & $121.67 \mathrm{bcd}$ \\
J2P2 & $31.40 \mathrm{~cd}$ & $67.93 \mathrm{bc}$ & $105.73 \mathrm{bcd}$ & $121.73 \mathrm{bcd}$ \\
J2P3 & $31.73 \mathrm{bc}$ & $68.13 \mathrm{bc}$ & $105.87 \mathrm{bc}$ & $121.87 \mathrm{bcd}$ \\
J3P1 & $32.27 \mathrm{~b}$ & $68.53 \mathrm{bc}$ & $105.93 \mathrm{bc}$ & $122.07 \mathrm{bc}$ \\
J3P2 & $33.60 \mathrm{a}$ & $69.13 \mathrm{~b}$ & $107.00 \mathrm{~b}$ & $123.53 \mathrm{~b}$ \\
J3P3 & $34.27 \mathrm{a}$ & $72.00 \mathrm{a}$ & $110.07 \mathrm{a}$ & $127.80 \mathrm{a}$ \\
\hline BNT 5\% & 0.85 & 1.41 & 1.84 & 2.01 \\
\hline
\end{tabular}

Keterangan : Angka-angka yang diikuti oleh huruf yang sama dalam kolom yang sama tidak berbeda nyata dengan uji BNT $5 \%$.

Pada Tabel 1, hasil pengamatan menunjukkan pertumbuhan tinggi tanaman pada umur 14 HST, 28 HST, 42 HST dan 56 HST perlakuan J3P3 lebih baik dibandingkan perlakuan yang lain, meskipun pada umur 14 HST tidak berbeda nyata antara rata-rata nilai tinggi perlakuan J3P3 dengan nilai $34.27 \mathrm{~cm}$ dan perlakuan J3P2 dengan nilai $33.60 \mathrm{~cm}$.

Hasil pada parameter tinggi tanaman ini dipengaruhi semakin rapatnya tajuk tanaman tinggi tanaman yang mengakibatkan kualitas cahaya yang sidik ragam dengan uji Fisher (uji - F pada taraf 5\% dan 1\%), apabila terjadi perbedaan nyata maka akan dilanjutkan dengan uji Beda Nyata Terkecil (BNT 5\%).

\section{HASIL DAN PEMBAHASAN}

\section{Tinggi tanaman}

Hasil analisis ragam menunjukkan bahwa terdapat interaksi antara perlakuan pola tanam jajar legowo dan kombinasi pupuk terhadap tinggi tanaman, pada umur pengamatan 14 hst, 28 hst, 42 hst dan 56 hst. (Tabel 1.) 
semaki meningkat dan $\mathrm{K}$ pada $\mathrm{KCl}$ berperan sebagai penguat batang. Sejalan dengan Muyasir, (2012) yang menyatakan pertambahan tinggi tanaman disebabkan karena tajuk tanaman yang semakin merapat mengakibatkan kualitas cahaya yang diterima menjadi menurun. Semakin rapat jarak tanam yang dipakai maka pertumbuhan tinggi tanaman akan semakin cepat karena tanaman saling berusaha mencari sinar matahari yang lebih banyak.

Pemberian ZA dapat meningkatkan serapan hara nitrogen oleh tanaman. Dengan semakin tinggi kandungan nitrogen maka penyerapan $P$ juga akan semain meningkat. Dengan terpenuhinya hara tanaman akan mampu mendukung pertumbuhan tanaman. $\mathrm{K}$ juga berpengaruh terhadap tinggi tanaman. $\mathrm{K}$ berperan dalam memperkuat batang tanaman. Dengan semakin tinggi serapan $\mathrm{K}$ maka pertumbuhan tanaman akan optimal. Pemupukan nitrogen dapat menunjang pertumbuhan tanaman padi sawah dan sebaliknya jika tidak diberikan akan menghambat pertumbuhan tanaman karena nitrogen meupakan unsur hara yang berfungsi memacu pertumbuhan tanaman (Syafitri et al. 2018). Tanaman yang tinggi akan berpengaruh saling menaungi diantara susunan daun yang tumbuh dan belum tentu akan menghasilkan gabah berisi secara maksimum (Setiawati, 2016).

\section{Jumlah Anakan dan Jumlah Anakan Produktif}

Hasil analisis ragam menunjukkan bahwa terdapat interaksi antara perlakuan pola jajar legowo dan kombinasi pupuk terhadap jumlah anakan dan jumlah anakan produkif (Tabel 2.).
Tabel 2. Rata rata Jumlah Anakan dan Jumlah Anakan Produktif

\begin{tabular}{clc}
\hline Perlakuan & \multicolumn{1}{c}{ JA } \\
(Batang) & $\begin{array}{c}\text { JAP } \\
\text { (Batanag) }\end{array}$ \\
\hline J1P1 & $29.13 \mathrm{bc}$ & $25.63 \mathrm{bc}$ \\
J1P2 & $30.00 \mathrm{~b}$ & $26.87 \mathrm{~b}$ \\
J1P3 & $33.33 \mathrm{a}$ & $28.67 \mathrm{a}$ \\
J2P1 & $28.13 \mathrm{~cd}$ & $24.30 \mathrm{~d}$ \\
J2P2 & $28.27 \mathrm{~cd}$ & $24.63 \mathrm{~cd}$ \\
J2P3 & $28.60 \mathrm{bcd}$ & $24.83 \mathrm{~cd}$ \\
J3P1 & $26.43 \mathrm{e}$ & $23.80 \mathrm{~d}$ \\
J3P2 & $27.37 \mathrm{de}$ & $23.93 \mathrm{~d}$ \\
J3P3 & 27.40 de & $24.23 \mathrm{~d}$ \\
\hline BNT 5\% & 1.65 & 1.28 \\
\hline Keterangan : Angka-angka yang diikuti oleh & huruf yang sama dalam \\
& kolom yang sama tidak \\
& berbeda nyata dengan uji \\
BNT 5 \%.
\end{tabular}

Pada Tabel 2, menunjukan bahwa hasil jumlah anakan pada perlakuan J1P3 membentuk jumlah anakan lebih banyak dibandingkan perlakuan yang lain. Perlakuan J1P3 membentuk anakan sejumlah 33.33 batang sedangkan perlakuan lain berkisar antara 26.43 hingga 30.00 batang.

Hasil demikian terjadi merupakan dampak dari penggunaan jarak tanam yang cukup lebar dan adanya baris yang kosong sehingga kondisi lingkungan tumbuh tanaman optimal. Semakin banyak lorong yang kosong pada pola tanam jajar legwo menghasilkan jumlah anakan yang lebih banyak. Hasil ini sejalan dengan Husnah (2010) jumlah anakan akan maksimal apabila tanaman memiliki sifat genetik yang baik ditambah dengan keadaan lingkungan yang menguntungkan atau sesuai dengan pertumbuhan dan perkembangan tanaman. Ditambahkan oleh Sari et al. (2014) yang menyatakan bahwa tipe jajar legowo 2:1 membentuk jumlah anakan total paling tinggi merupakan dampak dari banyaknya lorong 
yang kosong yang cukup lebar diantara barisan tanaman.

Dengan pola tanam jajar legowo 2:1 maka pemberian kombinasi pupuk Petroganik $500 \mathrm{~kg} \mathrm{ha}^{-1}+$ ZA $300 \mathrm{~kg}$. ha ${ }^{-1}+$ SP-36 75 kg. ha ${ }^{-1}+\mathrm{KCl} 50 \mathrm{~kg}$. ha ${ }^{-1}$ (J3) dapat diserap secara efektif oleh tanaman akibat faktor lingkungan yang optimal. Pemberian nitrogen dapat meningkatkan jumlah anakan, selain itu unsur hara belerang (S) yang terdapat pada pupuk ZA dan SP 36 dapat memacu pertumbuhan anakan. Pemupukan yang berkombinasi sangat mempengaruhi pertumbuhan tanaman padi. Sejalan dengan Mashtura et al, (2013) pemupukan Phosfat dan sulfur berpengaruh nyata terhadap jumlah anakan dan jumlah anakan produktif, Dengan demikian Jumlah pupuk sulfur sangat mendukung peningkatan panjang malai, semakin tinggi dosis pemupukan sulfur yang diberikan maka jumlah malai semakin meningkat.

Jumlah anakan produktif yang paling banyak adalah Perlakuan J1P3 dengan jumlah anakan produktif 28.67 batang. Hal ini karena langsung dipengaruhi oleh jumlah anakan yang telah terbentuk sebelumnya. Sejalan dengan Husnah, (2010) yang menyatakan bahwa jumlah anakan produktif merupakan anakan yang berkembang lebih lanjut den menghasilkan malai, tanaman padi potensi pembentukan anakan produktif terlihat dari jumlah anakan, pembentukan anakan dipengaruhi oleh faktor lingkungan. Selain itu juga dari faktor terpenuhunya unsur hara yang dibutuhkan oleh tanaman. Kombinasi pemupukan organik dan anorganik yang berimbang sangat mempengaruhi pertumbuhan tanaman padi (Ramadhan, 2014)

\section{Panjang Malai}

Hasil analisis ragam menunjukan bahwa terdapat interaksi antara perlakuan pola tanam jajar legowo dan kombinasi pupuk terhadap panjang malai pada umur pengamatan 56 hst dan 70 hst. Pengamatan panjang malai pada umur 70 HST perlakuan J1P3 dengan nilai $30.80 \mathrm{~cm}$ lebih baik dibandingkan perlakuan yang lain. Meskipun pada umur 56 HST tidak berbeda nyata antara nilai rata-rata perlakuan dengan nilai $22.90 \mathrm{~cm}$ dan perlakuan J1P2 dengan nilai $22.27 \mathrm{~cm}$ (Tabel 3.)

Tabel 3. Rata rata panjang malai

\begin{tabular}{ccc}
\hline \multirow{2}{*}{ Perlakuan } & \multicolumn{2}{l}{$\begin{array}{l}\text { Rata rata panjang malai } \\
\text { ( } \mathrm{cm}) \text { pada pengamatan } \\
\text { umur }\end{array}$} \\
\cline { 2 - 3 } & $56 \mathrm{HST}$ & $70 \mathrm{HST}$ \\
\hline J1P1 & $20.77 \mathrm{~b}$ & $30.17 \mathrm{~b}$ \\
J1P2 & $22.27 \mathrm{a}$ & $30.27 \mathrm{~b}$ \\
J1P3 & $22.90 \mathrm{a}$ & $32.80 \mathrm{a}$ \\
J2P1 & $19.83 \mathrm{bc}$ & $29.60 \mathrm{bc}$ \\
J2P2 & $19.90 \mathrm{bc}$ & $29.93 \mathrm{bc}$ \\
J2P3 & $20.23 \mathrm{bc}$ & $30.13 \mathrm{~b}$ \\
J3P1 & $19.33 \mathrm{c}$ & $28.13 \mathrm{~d}$ \\
J3P2 & $19.37 \mathrm{c}$ & $28.87 \mathrm{~cd}$ \\
J3P3 & $19.57 \mathrm{c}$ & $28.93 \mathrm{~cd}$ \\
\hline BNT 5 \% & 0.93 & 1.19 \\
\hline Keterangan : Angka-angka yang diikuti oleh & huruf yang sama dalam \\
& kolom yang sama tidak \\
& berbeda nyata dengan uji \\
& BNT 5 \%
\end{tabular}

J1P3 membentuk malai yang lebih panjang merupakan dampak dari kondisi lingkungan yang optimal dengan semakin banyak lorong diantara baris tanaman sehingga tanaman dapat memanfaatkan lingkungan sekitar guna mendukung pertumbuhannya. Daun pada perlakuan pola tanam jajar legowo 2:1 (J1) mendapatkan cahaya dari matahari secara baik tanpa adanya persaingan, dengan 
pertumbuhan daun yang baik akan berpengaruh pada proses fotosintesis yang akan menghasilkan fotosintat guna pembentukan malai dan pengisian bulir. Tentunya pembentukan malai ini juga dipengaruhi oleh faktor unsur $\mathrm{N}, \mathrm{P}, \mathrm{K}$ dan $\mathrm{S}$ yang tercukupi akibat tidak adanya persaingan akar tanaman dalam penyerapan unsur hara. Pembentukan malai ini diharapkan nantinya juga akan mempengaruhi jumlah bulir per malai.

Kombinasi pemupukan antara organik dan anorganik yang berimbang sangat mempengaruhi pertumbuhan tanaman padi. Sejalan dengan Sari et al. (2014) panjang malai merupakan salah satu komponen penting karena semakin panjang malai maka jumlah bulir per malai akan semakin meningkat. Jumlah pupuk sulfur sangat mendukung peningkatan panjang malai, semakin tinggi dosis pemupukan sulfur yang diberikan maka jumlah malai semakin meningkat, Phosfat yang diserap tanaman dalam bentuk $\mathrm{H}_{2} \mathrm{PO}_{4}$ membantu pertumbuhan tanaman muda menjadi dewasa serta mempercepat pertumbuhan malai dan gabah (Mashtura et $a l .2013$ ).

\section{Jumlah Bulir Per Malai, Berat Gabah Basah Per Sampel, Berat Gabah Kering Per Sampel Dan Berat 1000 Bulir}

Hasil analisis ragam menunjukan bahwa terdapat interaksi antara perlakuan pola tanam jajar legowo dan kombinasi pupuk terhadap jumlah bulir per malai, berat gabah basah per sampel, berat gabah kering per sampel dan berat berat 1000 bulir. Perlakuan J1P3 menghasilkan jumlah bulir per malai, berat gabah basah per sampel, berat gabah kering per sampel dan berat berat 1000 bulir yang lebih banyak (Tabel 4.)

Tabel 4. Jumlah bulir per malai, Berat gabah basah per sampel, Berat gabah kering per sampel dan Berat 1000 bulir

\begin{tabular}{cllll}
\hline PERLAKUAN & \multicolumn{1}{c}{ JBM } & \multicolumn{1}{c}{ BGBS } & \multicolumn{1}{c}{ BGKS } & \multicolumn{1}{c}{ BSB } \\
\hline J1P1 & $282.40 \mathrm{bc}$ & $229.60 \mathrm{bc}$ & $206.84 \mathrm{bc}$ & $30.20 \mathrm{~b}$ \\
J1P2 & $284.08 \mathrm{~b}$ & $231.27 \mathrm{~b}$ & $215.78 \mathrm{~b}$ & $30.27 \mathrm{~b}$ \\
J1P3 & $290.90 \mathrm{a}$ & $236.87 \mathrm{a}$ & $228.83 \mathrm{a}$ & $32.60 \mathrm{a}$ \\
J2P1 & $278.89 \mathrm{~cd}$ & $226.13 \mathrm{~cd}$ & $197.18 \mathrm{~d}$ & $29.60 \mathrm{bc}$ \\
J2P2 & $280.04 \mathrm{bc}$ & $227.27 \mathrm{bc}$ & $199.59 \mathrm{~cd}$ & $29.93 \mathrm{bc}$ \\
J2P3 & $280.21 \mathrm{bc}$ & $227.43 \mathrm{bc}$ & $201.04 \mathrm{~cd}$ & $30.13 \mathrm{~b}$ \\
J3P1 & $265.70 \mathrm{e}$ & $213.07 \mathrm{e}$ & $193.55 \mathrm{~d}$ & $27.87 \mathrm{~d}$ \\
J3P2 & $274.89 \mathrm{~d}$ & $222.17 \mathrm{~d}$ & $194.52 \mathrm{~d}$ & $28.87 \mathrm{~cd}$ \\
J3P3 & $278.56 \mathrm{~cd}$ & $225.80 \mathrm{~d}$ & $196.69 \mathrm{~d}$ & $28.93 \mathrm{~cd}$ \\
\hline
\end{tabular}

Keterangan : Angka-angka yang diikuti oleh huruf yang sama dalam kolom yang sama tidak berbeda nyata dengan uji BNT $5 \%$, JBM = Jumlah bulir per malai, BGBS = Berat gabah basah per sampel, BGKS = Berat gabah kering per sampel, BSB = Berat 1000 bulir

Tanaman dengan sistem jajar legowo juga 2:1 juga lebih tahan terhadap serangan penyakit, karena sirkulasi udara lebih baik karena banyaknya lorong. Lorong kosong lebih banyak dan lebih sedikit jumlah populasi sehingga tanaman dapat mengoptimalkan pemberian pupuk. Pemberian pupuk pupuk Petroganik $500 \mathrm{~kg}$ 
$\mathrm{ha}^{-1}+$ ZA $300 \mathrm{~kg} \cdot \mathrm{ha}^{-1}+$ SP $3675 \mathrm{~kg} \cdot \mathrm{ha}^{-1}+$ $\mathrm{KCl} 50 \mathrm{~kg}$. ha ${ }^{-1}$ dapat memenuhi kebutuhan unsur hara dan tidak ada persaingan antar tanaman yang berpengaruh pada fase vegetatif. Aplikasi pupuk $\mathrm{N}, \mathrm{P}$, dan $\mathrm{K}$ secara tunggal dapat memberikan pengaruh yang lebih baik terhadap pertumbuhan dan hasil produksi padi. Pembentukan bulir padi dipengaruhi fase vegetatif. Pertumbuhan vegetatif yang optimal akan menunjang pertumbuhan generatif. Fase vegetatif merupakan fase yang sangat menentukan produktivitas tanaman. Pada fase ini seluruh energi difokuskan untuk pertumbuhan akar, batang dan daun, jika pertumbuhan akar, batang dan daun sehat dan optimal maka akan mampu menghasilkan produtivitas yang tinggi. Pertumbuhan akar yang sehat akan mempengaruhi penyerapan unsur hara yang terdapat padah tanah secara baik. Pertumbuhan batang dan daun akan mempengaruhi proses fotosintesis, dari daun yang sehat akan menghasilkan fotosintat guna perkembangan bulir yang optimal. Kualitas dan kuantitas gabah dipengaruhi keberhasilan pengisian bulir pada saat proses fotosintesis, jika fotosintesis tidak maksimal akan mengakibatkan terjadinya gabah hampa.

Menurut Yoshida (1981) kerapatan populasi tanaman berdampak pada kuantitas malai pertanaman yang terbentuk, selanjutnya dapat mempengaruhi produktifitas kering tanaman. Prodiksi kering tanaman dipengaruhi keberhasilan pengisian bulir pada saat proses fotosintesis, jika proses fotosintesis tidak maksimal akan mengakibatkan terjadinya gabah hampa.

Nuraya, et. al (2017) mengemukakan, semakin lebar jarak tanam pada model perlakuan maka akan semakin baik pula proses fotosintesis yang terjadi pada pola tanam tersebut dan hasil dari fotosintesis atau asimilat tersebut dapat dialokasikan langsung ke organ generatif atau untuk pembentukkan serta pengisian malai sehingga prosentase gabah hampa dapat diminimalkan. Penggunaan pola tanam jajar legowo 2:1 dapat meningkakan hasil produksi sebesar 6.9 t.ha ${ }^{-1}$ atau meningkat sebesar (56\%) jika dibandingkan sistem tanam konvensional sebesar 4,5 t.ha ${ }^{-1}$.

Hal ini sejalan dengan penelitian dengan penelitian Sumardi (2010) bahwa populasi tanaman berdampak pada persentase bulir bernas, peningkatan persentase bulir bernas jika populasi tanaman semakin rendah. Semakin lebar jarak tanam pada model perlakuan maka akan semakin baik pula proses fotosintesis yang terjadi pada pola tanam rersebut dan hasil dari fotosintesis atau asimilat terdsebut dapat dialokasikan langsung ke organ generatif atau untuk pembentukkan serta pengisian malai sehingga prosentase gabah hampa dapat diminimalkan (Nuraya, et al. 2017).

Selanjutnya penambahan pupuk guna pemenuhan unsur hara yang dibutuhkan oleh tanaman. Penggunaan pupuk N, P, dan $K$ secara tunggal memberikan pengaruh yang nyata terhadap pertumbuhan dan beberapa komponen hasil padi (Arafah dan Sirappa, 2003). Kalium dalam tanaman berfungsi dalam pembentukan gula dan pati, translokasi gula, aktivitas enzim dan pergerakan stomata. Peningkatan bobot dan kandungan gula pada buah. Sejalan dengan Marschner, (2012) dalam Darma, (2018) menyatakan pada masa generatif unsur $\mathrm{K}$ memiliki peranan penting dalam proses pembesaran atau pengisian buah, 
rasa dan bobot. Unsur K diserap oleh tanaman berfungsi untuk memperlancar fosintesis, membantu pembentukan protein, karbohidrat sebagai katalisator dalam transformasi tepung, gula dan lemak dalam tanaman. Haris et al. (2014) menyatakan bahwa kalium dalam tanaman berfungsi dalam pembentukan gula dan pati, translokasi gula, aktivitas enzim dan pergerakan stomata. Peningkatan bobot dan kandungan gula pada buah dapat dilakukan dengan mengefisienkan proses fotosintesis pada tanaman dan meningkatkan traslokasi fotosintat kebagian buah. Pembentukan bulir padi dipengaruhi fase vegetatif. Pertumbuhan vegetatif yang optimal akan menunjang pertumbuhan generatef. Bobot biji sangat ditentukan oleh bentuk dan ukuran biji pada suatu varietas. Pemberian pupuk ZA yang mengandung $\mathrm{N}$ dan $\mathrm{S}$ berpengaruh pada pembentukkan bulir dan aroma. Fungsi sulfur yaitu kuantitas padi berkaitan dengan ukuran dan jumlah yang dihasilkan (Syafitri et al. 2018).

\section{Berat gabah kering per hektar}

Hasil analisis ragam menunjukan terdapat interaksi antara perlakuan pola tanam jajar legowo dan kombinasi pupuk terhadap berat gabah kering per hektar pada pengamatan panen. Nilai rerata tertinggi pada pengamatan berat per hektar adalah $10.81 \mathrm{t}$. ha ${ }^{-1}$ pada perlakuan J1P3 (Pola tanam jajar legowo 2:1 dan Kombinasi pupuk Petroganik $500 \mathrm{~kg} \mathrm{ha}^{-1}+$ ZA $300 \mathrm{~kg}$. ha ${ }^{-1}+$ SP $3675 \mathrm{~kg} \cdot \mathrm{ha}^{-1}+\mathrm{KCl} 50$ kg. $\mathrm{ha}^{-1}$ ). Dibandingkan perlakuan yang lain J1P3 menunjukan hasiil yang lebih baik. Sedangkan J3P1 menunjukan hasil paling sedikit dengan nilai 10.20 t. ha ${ }^{-1}$. ( Tabel 5).
Table 5. Berat gabah kering per hektar

\begin{tabular}{lc}
\hline Perlakuan & $\begin{array}{l}\text { Rata rata berat gabah kering } \\
\text { per hektar }(\mathrm{t})\end{array}$ \\
\hline J1P1 & $10.39 \mathrm{bc}$ \\
J1P2 & $10.50 \mathrm{~b}$ \\
J1P3 & $10.81 \mathrm{a}$ \\
J2P1 & $10.37 \mathrm{bcd}$ \\
J2P2 & $10.37 \mathrm{bcd}$ \\
J2P3 & $10.39 \mathrm{bc}$ \\
J3P1 & $10.20 \mathrm{~d}$ \\
J3P2 & $10.24 \mathrm{~cd}$ \\
J3P3 & $10.29 \mathrm{~cd}$ \\
\hline BNT 5\% & 0.18 \\
\hline Keterangan : Angka-angka yang diikuti oleh \\
huruf yang sama dalam \\
kolom yang sama tidak \\
berbeda nyata dengan uji \\
BNT $5 \%$
\end{tabular}

J1P3 menghasilkan berat per hektar yang banyak merupakan dampak dari pola tanam jajar legowo 2 : 1 (J1) dapat memberikan kondisi lingkungan yang optimal dan Pemberian pupuk Petroganik $500 \mathrm{~kg} \mathrm{ha}^{-1}+$ ZA $300 \mathrm{~kg}$. ha ${ }^{-1}+$ SP $3675 \mathrm{~kg}$. $\mathrm{ha}^{-1}+\mathrm{KCl} 50 \mathrm{~kg}$. ha ${ }^{-1}$ (J3) dapat memenuhi kebutuhan unsur hara tanaman. Tiap baris tanaman mendapatkan lebih banyak sinar matahari dan unsur hara tanpa adanaya kompetisi, sehingga fotosintesis tanaman dapat berjalan optimal. Kondisi lingkungan tanaman dapat menentukan hasil yang baik pada wujud dan ukuran bulir yang nantinya dapat mempengaruhu bobot biji.

Pola tanam jajar legowo dapat memberikan bentuk yang lebih besar dan seragam. Unsur sulfur dan kalium mempunyai fungsi guna meningkatkan kualitas dan kuantitas bulir.

Amiroh, (2018) menyatakan, tinggi rendahnya berat biji tergantung dari banyak tidaknya bahan kering yang terkandung dalam biji. Bahan kering dalam biji diperoleh dari fotosintesis yang selanjutnya dapat digunakan untuk 
pengisian biji. Tingkat keberhasilan pengisian bulir pada saat proses fotosintesis mempengaruhi kualitas dan kuantitas gabah, jika fotosintesis tidak maksimal akan mengakibatkan terjadinya gabah hampa.

Menurut Haris et al. (2014) yang menyatakan bahwa kalium dalam tanaman berfungsi dalam pembentukan gula dan pati, translokasi gula, aktivitas enzim dan pergerakan stomata. Peningkatan bobot dan kandungan gula pada buah dapat dilakukan dengan mengefisienkan proses fotosintesis pada tanaman dan meningkatkan translokasi fotosintat kebagian buah. Pembentukan bulir padi dipengaruhi fase vegetatif. Pertumbuhan vegetatif yang optimal akan menunjang pertumbuhan generatef. Bobot biji sangat ditentukan oleh bentuk dan ukuran biji pada suatu varietas. Pemberian pupuk ZA yang mengandung $N$ dan $S$ berpengaruh pada pembentukkan bulir dan aroma. Fungsi sulfur yaitu kuantitas padi berkaitan dengan ukuran dan jumlah yang dihasilkan (Syafitri et al. 2018).

\section{SIMPULAN DAN SARAN}

\section{Simpulan}

Terdapat interaksi antara antara perlakuan macam pola tanam jajar legowo dan kombinasi pupuk terhadap tinggi tanaman (14 hst, 28 hst, 42 hst dan 56 hst), jumlah anakan (14 hst, 28 hst, 42 hst dan 56 hst) , Jumlah anakan produktif, panjang malai (56 Hst dan 70 Hst), jumlah gabah per malai, berat gabah basah per sampel, berat gabah kering per sampel, berat gabah kering per hektar, berat 1000 biji.

Perlakuan terbaik pada pengamatan berat gabah kering per hektar nilai tertiggi terdapat pada perlakuan
J1P3(pola tanam jajar legowo 2:1 dan kombinasi pupuk Petroganik $500 \mathrm{~kg}$ ha-1 + ZA 300 kg. ha-1 + SP 3675 kg. ha-1 + KCl 50 kg. ha-1) menghasilkan nilai 10.81 t.ha-1.

\section{SARAN}

Hasil penelitian ini secara umum berpengaruh nyata pada pola tanam jajar legowo 2:1 dan kombinasi pupuk Petroganik $500 \mathrm{~kg} \mathrm{ha}^{-1}+\mathrm{ZA} 300 \mathrm{~kg}$. ha ${ }^{-1}+\mathrm{SP}$ $3675 \mathrm{~kg}$. ha ${ }^{-1}+\mathrm{KCl} 50 \mathrm{~kg}$. ha ${ }^{-1}$ dengan varietas sertani 14 untuk musim tanam ke 2, karena itu disarankan perlu penelitian lebih lanjut sesuai kondisi lingkungan dan penggunaan varietas lokal lebih kaya akan genetika senggia perlu adanya penelitian lebih lanjut pada teknologi budidaya yang berkembang.

\section{DAFTAR PUSTAKA}

Abdulrachman S, Mejaya M J, Agustiani N, Gunawa I, Sasmita P, Guswara A. 2013. Sistem Tanam Legowo. Badan Penelitian dan Pengembangan Pertanian. Kementerian Pertanian: Jakarta.

Amiroh, 2018. Peningkatan Pertumbuhan dan Produksi Padi (Oryza sativa L.) Melalui Aplikasi Sistem Tanam Jajar Legowo dan Macam Varietas: Agroradix 1 (2) :52-62

Arafah dan M. P. Sirappa. 2003. Kajian penggunaan jerami dan pupuk $\mathrm{N}, \mathrm{P}$, dan $\mathrm{K}$ pada lahan sawah irigasi. Ilmu Tanah dan Lingkungan 4(1):15-24. 
Anonimous, 2017. Optimis Produksi Beras 2018 ,Kementan Pastikan Harga Beras Stabil. http://www.pertanian.go.id/h ome/?show=news\&act=view\& $i d=2614$ (Diakses pada 28 Desember 2018)

Darma, B. 2018. Kajian Dosis Pupuk $\mathrm{KNO}_{3}$ Dan Jarak Tanam Terhadap Pertumbuhan Dan Produksi Tanaman Tomat (Licopersicum esculentum Mill)

Haris dan Veronica Kristiani, 2014. Studi pemupukan Kalium Terhadap pertumbuhan dan Hasil Jagung Manis (Zea mays saccharata sturt)Varietas Super bee. Jurnal Untan dalam http: // jurnal.untan.ac.id (diakses pada 29 Juni 2019)

Husnah, Y. 2010 Pengaruh Jarak Tanam Terhadap Pertumbuhan Dan Produksi Padi Sawah (Oryza Sativa L) varietas IR dengan metode SRI (System of rice intensification). Jurnal SAGU 9(1):21-27

Mashtura et al, 2013. Pengaruh pemupukan phosfat dan sulfur terhadap pertumbuhan dan serapan hara serta efisiensi hasil padi sawah (oryza sativa L.) Jurnal manajemen sumberdaya lahan. 2(3): 285295

Muyassir , 2012, Efek Jarak Tanam, Umur Dan Jumlah Bibit Erhadap Hasil Padi Sawah (Oryza Sativa L.) Jurnal Manajemen Sumberdaya Lahan, Volume 1, Nomor 2,Desember 2012: Hal. 207-212
Nuraya, et al 2017 . kajian beberapa macam sistem tanam dan jumlah biit per lubang tanam padaproduksi padi sawah (Oryza sativa L.) Jurnal Produksi Tanaman. 5 (8) : 1337-1345.

Ramadhan, F. 2014. Parameter genetic Beberapa Varietas Padi (Oryza sativa L.) Pada Kondisi Media Berbeda.Universitas Syiah kuala. Skripsi.Banda Aceh.

Sari et al. 2014. Pengujian Berbagai Tipe Tanam Jajar Legowo Terhada Hasil Padi Swah. Akta Agrosia 17(2):116-125

Setiawati, 2016 Pengaruh pupuk hayati padat terhadap serapan $\mathrm{N}$ dan $\mathrm{P}$ tanaman, komponen hasil dan hasil padi sawah (Oryza sativa L.)

Jurnal Agroekotek 8 (2) : 120 130

Sumardi. 2010. Produktivitas padi sawah pada kepadatan berbeda. Ilmu-ilmu

Pertanian Indonesia XII (1) : 49-54.

Syafitri et al. (2018)Pengaruh Aplikasi Biourine Sapi dan Pupuk ZA Terhadap Pertumbuhan dan Produksi Tanaman Padi (Oryza sativa L.). Jurnal Prodoksi Tanaman 6 (7) : 1506 - 1512

Wahzudi, 2012. Bertanam Tomat Dalam Pot dan Kebun Mini Agromedia Jakarta

Yoshida S. 1981. Fundamentals of Rice Crop Science. Los Banos: International

Rice Research Institute. 268 hlm. 